\title{
Treatment with thiamine hydrochloride and astaxanthine for the prevention of yolk-sac mortality in Baltic salmon fry (M74 syndrome)
}

\author{
Perttu Koski ${ }^{1, *}$, Maarit Pakarinen ${ }^{2}$, Tarja Nakari ${ }^{3}$, Antti Soivio ${ }^{4}$, Kirsi Hartikainen ${ }^{2}$ \\ ${ }^{1}$ National Veterinary and Food Research Institute, Oulu Regional Laboratory, PO Box 517, 90101 Oulu, Finland \\ ${ }^{2}$ National Veterinary and Food Research Institute, Department of Chemistry, PO Box 368, 00231 Helsinki, Finland \\ ${ }^{3}$ Finnish Environmental Institute, Hakuninmaantie 4-6, 00430 Helsinki, Finland \\ ${ }^{4}$ Finnish Game and Fisheries Research Institute, PO Box 6, 00721 Helsinki, Finland
}

\begin{abstract}
Two practical methods are reported for treating feral Baltic salmon with thiamine hydrochloride against M74 syndrome (abnormally high yolk-sac fry mortality of the Baltic salmon). Both bathing of the yolk-sac fry in thiamine hydrochloride (1000 $\mathrm{mg} \mathrm{l}^{-1}, 1 \mathrm{~h}$ ) and a single intraperitoneal injection given to the female brood fish $\left(100 \mathrm{mg} \mathrm{kg}^{-1}\right.$ fish) during the summer 3 mo before stripping were shown to elevate the whole body total thiamine concentration in the fry. Both treatments were also shown to be effective in preventing mortality due to M74 syndrome. The effect of bathing the yolksac fry was shown to be dose-dependent. The results support the view that there is a causal relationship between the thiamine status of the yolk-sac fry and M74 mortality. An intraperitoneal injection of astaxanthine suspension administered to the female brood fish (11 $\mathrm{mg} \mathrm{kg}^{-1}$ fish) in the summer 3 mo before stripping elevated the astaxanthine concentration in the eggs but did not affect mortality due to M74 syndrome. An interaction between astaxanthine and thiamine may occur in the developing embryo or yolk-sac fry, however. No association could be demonstrated between the various thiamine hydrochloride treatment practices and hepatic cytochrome $\mathrm{P} 450$ dependent 7 -ethoxyresorufin- $\mathrm{O}$ deethylase (EROD) activity in the yolk-sac fry. An injection of thiamine hydrochloride into the peritoneal cavity of wild Baltic salmon females could be used to raise thiamine concentrations in their offspring in the rivers. The effect on smolt production in Finnish Baltic salmon rivers needs to be investigated further, however.
\end{abstract}

KEY WORDS: Salmo salar Baltic salmon - Yolk-sac fry $\cdot$ M74 syndrome - Thiamine hydrochloride Astaxanthine $\cdot$ EROD activity $\cdot$ Prevention

\section{INTRODUCTION}

Abnormally high mortality (ca $90 \%$ ) was observed among farmed yolk-sac fry of the Baltic salmon (the Baltic group of Salmo salar L.) originating from feral brood fish in northern Gulf of Bothnia in 1992-1996. Mortality at the same developmental stage has been also observed since 1974 in Sweden, where the disease is called M74 (Norrgren et al. 1993). The same authors observed that the total hepatic cytochrome P450 content was significantly increased in adults that produced M74-affected yolk-sac fry compared with adults

\footnotetext{
•E-mail: perttu.koski@eela.fi
}

that produced normal yolk-sac fry. The hepatic cytochrome P450 dependent 7-ethoxyresorufin-O-deethylase (EROD) activity was found to be 12 times higher in M74-affected yolk-sac fry than that in normal yolk-sac fry from hatchery-reared brood fish and 1.7 times higher than in normally developing yolk-sac fry from feral brood fish. These findings, together with the ultrastructural changes present in the liver of the sick yolk-sac fry and the females producing these, led the authors to propose a toxicological etiology for the syndrome (Norrgren et al. 1993). The letter $M$ in the name of the syndrome comes from the Swedish word for environmentally caused, 'miljöbetingad' (Börjeson et al. 1995). Vuorinen et al. (1997) reported an association between yolk-sac mortality and some polychlorinated 
dibenzofurans and coplanar polychlorinated biphenyls (PCBs) in their material of River Simo salmon in Finland in 1.988-92.

A mortality syndrome resembling M74 has also been described in landlocked Atlantic salmon in several of the Finger Lakes in New York, USA (Fisher et al. 1994, 1995), and has been successfully treated with thiamine (Fisher et al. 1994, 1996a, b). Analysis of the thiamine contcentration of the M74 and control fry and preliminary trials with thiamine treatment of Baltic salmon in Sweden in 1994 showed that thiamine could also be used in the therapy of M74 $(\mathrm{H}$. Börjeson pers. comm. 1994). Bylund \& Lerche (1995) reported successful thiamine treatment of the fry of 1 Baltic salmon female with $\mathrm{M74}$-like clinical signs.

Börjeson et al. (1995) reported that yolk-sac fry originating from paler eggs show a higher prevalence of M74-related mortality than those from eggs with a good pigmentation, while Lignell (1995) found that the concentration of the carotenoid astaxanthine in the yolk-sac fry was in negative correlation with mortality caused by the M74 syndrome. Pettersson \& Lignell (1996) found that salmon eggs from locations without M74 syndrome had a higher concentration of astaxanthine than those of feral Baltic salmon.

We examine here the effect of thiamine hydrochloride treatment of yolk-sac fry and female brood fish for preventing M74 in feral Baltic salmon. An astaxanthine injection given to the female brood fish was also tested.

\section{MATERIAL AND METHODS}

Fish, management and treatments. Thiamine bathing of the yolk-sac fry (Expt 1): Seven Baltic salmon females caught from near the mouth of the River Simo in June 1994 were stripped in October (2 to 3 strippings per female) and the fertilized ova and yolk-sac fry incubated in the water of the River Kemi at the Lautiosaari State Fish Hatchery, Keminmaa, Finland. On 7 June 1995,150 to 200 yolk-sac fry from each female were bathed in 500, 250 or $12500 \mathrm{mg} \mathrm{l}^{-1}$ thiamine hydrochloride Ph. Eur. (Oriola, Finland) for 1 h. A fourth series of fry, sham treated with water from the River Kemi, served as controls. Thus the experiment comprised a total of 28 groups of yolk-sac fry. The thiamine hydrochloride was dissolved in hatchery water and the $\mathrm{pH}$ of the solution was adjusted to that of the hatchery water ( $\mathrm{pH}=6.2$ to 6.4 ) with sodium hydroxide p.a. (Merck, Germany). The water temperature during the experiment varied in the range 13 to $18^{\circ} \mathrm{C}$ (see Fig. $2 \mathrm{a}$, 'Results'), the temperature during immersion being $15^{\circ} \mathrm{C}$. The flow rate to the incubation troughs averaged around $12 \mathrm{l} \mathrm{min}-1$, and the water was supplementarily oxygenated during the treatment. The fry were 282 to 383 day-degrees old (from fertilization) at the time of the treatment and showed no signs of any disorder. The fish were using their yolk-sac during the experiment, and this became exhausted at an age of 500 to 550 day-degrees. The test fry were not fed in the trays, but their siblings, which were being used for normal production of the farm (and were treated with $1000 \mathrm{mg}$ $\mathrm{l}^{-1}$ thiamine hydrochloride for $1 \mathrm{~h}$ ) had begun to eat artificial feed at the same time as this experiment ended.

One day before the thiamine treatment the yolk-sac fry were put on $9 \times 18 \mathrm{~cm}^{2}$ aluminium trays, 3 of which were placed side by side in 2 plastic hatchery troughs. The trays representing the different treatment groups were placed randomly in the troughs. The fish were bathed in thiamine solution while on their trays. They were then observed daily and the dead individuals counted and taken away every 1 to $3 \mathrm{~d}$. A sample of yolk-sac fry from each of the 7 females was taken for thiamine analysis 1 to $2 \mathrm{~d}$ before the bathing, and the same was done later for fish found lying on their side on the bottom of the tray, the numbers of which were included in the mortality for the date in question. Normally behaving fry which had been bathed in $12500 \mathrm{mg} \mathrm{l}^{-1}$ thiamine hydrochloride and represented the progeny of 2 of the females were also taken for analysis at the end of the experiment.

Injection trials with adult females (Expt 2): A total of 48 Baltic salmon brood fish were caught with seine nets during the last 2 wk of June and the first week of July in 1995 from one point on the River Kemi, just downstream of the dam of the first hydroelectric power station, about $10 \mathrm{~km}$ from the river mouth. They were transferred to 2 circular glass-fibre tanks of diameter $6 \mathrm{~m}$ with a water depth of $1 \mathrm{~m}$ and were kept unfed in these tanks until stripping on October 12-17, 1995. During their first week in the tank they were anaesthesized with buffered tricaine methane sulphonate (MS$222^{\mathrm{TM}}$ ), measured for total length and weight, marked with a Carlin tag, and given a single intramuscular injection of ampicillin trihydrate $\left(15 \mathrm{mg} \mathrm{kg}^{-1}\right.$, Penbritin vet. ${ }^{\mathrm{T}} 150 \mathrm{mg} \mathrm{ml}^{-1}$, Orion-Farmos, Finland) to prevent clinical furunculosis. At the same time 4 treatment groups were established:

(1) Thiamine group, 19 females: treated with an intraperitoneal (i.p.) injection of thiamine hydrochloride at a dose of ca 100 (92 to 105) $\mathrm{mg} \mathrm{kg}^{-1}$. The solution was made by dissolving crystalline thiamine hydrochloride $\mathrm{Ph}$. Eur. (Oriola, Finland) in distilled water and adjusting the $\mathrm{pH}$ of the solution to between 7 and 8 with sodium hydroxide to achieve a thiamine hydrochloride concentration of $125 \mathrm{mg} \mathrm{ml}^{-1}$ in the solution.

(2) Astaxanthin group, 10 females: treated with an i.p. injection of astaxanthine at a dose of ca 11 (10 to 
13) $\mathrm{mg} \mathrm{kg}^{-1}$. The crystalline astaxanthine (Roche, Finland) was suspended in a $0.5 \%$ solution of methyl cellulose Ph. Eur. 1500 (Tamro, Finland) in distilled water to achieve an astaxanthine concentration of $12.5 \mathrm{mg}$ $\mathrm{ml}^{-1}$.

(3) Thiamine + astaxanthine group, 10 females: treated with i.p. injections of both thiamine hydrochloride, ca 100 (99 to 106) $\mathrm{mg} \mathrm{kg}^{-1}$, and astaxanthine, ca 11 (10 to 13 ) $\mathrm{mg} \mathrm{kg}^{-1}$. The liquids were made up as described above.

(4) Control group, 9 females: did not receive any injection

The thiamine and astaxanthine solutions were prepared just beforehand and kept in melting ice during the injection procedure. The eggs for thiamine and astaxanthine analysis were collected from normally stripped roe before fertilization. About $1 \mathrm{l}$ of fertilized eggs from each female was incubated in ordinary $45 \times$ $45 \mathrm{~cm}^{2}$ plastic trays (Ewos ${ }^{\mathrm{TM}}$ ), 5 of which were placed end to end in plastic hatchery troughs. About 235 daydegrees after fertilization (May 7, 1996), before any M74 mortality had been recorded in the control group, until the end of the experiment (about 583 daydegrees) 100 yolk-sac fry from each female were kept on similar $9 \times 18 \mathrm{~cm}^{2}$ aluminium trays as the fry in Expt 1 and daily mortalities were counted and dead fry removed. The samples for thiamine and astaxanthine analysis were taken at an age of 346 to 356 daydegrees from the yolk-sac fry on the $45 \times 45 \mathrm{~cm}^{2}$ plastic trays before the appearance of any M74 signs. Water temperatures during the period covering approximately 235 to 583 day-degrees are shown in Fig. 2b ('Results').

Expt 3: Some of the yolk-sac fry from 8 of the thiamine-injected females and from 5 females in the control group of Expt 2 were bathed with $1000 \mathrm{mg} \mathrm{l}^{-1}$ thiamine hydrochloride for $1 \mathrm{~h}$ at an age of about 360 day-degrees. The treatment was similar to that in Expt 1, but the yolk-sac fry were kept in the ordinary hatchery trays used at the farm. The rest of the fry was left untreated. As M74 mortality had already begun in some of the control groups in Expt 2, the material was supplemented with the yolk-sac fry from 3 noninjected Baltic salmon females of the River Simo strain. Four test series were established:

(1) Yolk-sac fry of the females injected with thiamine hydrochloride, fry not treated, 8 groups (symbol $\mathrm{C}$ in Fig. 4, 'Results')

(2) Yolk-sac fry of the above females, fry bathed in thiamine hydrochloride, 8 groups (symbol B in Fig. 4, 'Results')

(3) Yolk-sac fry of non-injected females, fry not treated, 8 groups ( $F$ in Fig. 4)

(4) Yolk-sac fry of the above females, bathed in thiamine hydrochloride, 5 groups (symbol E in Fig. 4).
Daily mortalities were counted and dead fry removed. The fry taken for the measurement of total thiamine concentration were of the ages indicated in Fig. 4, 'Results'. Because of the onset of M74 mortality, there was not enough material for thiamine analysis in test series 3 ( $F$ in Fig. 4). The relative increase in total thiamine concentration (RIT) in the fry originating from the injected females was determined according to the formula (see Fig. 4 for symbols): RIT = (conc. $\mathrm{B}-$ conc. $\mathrm{C}$ ) $/$ conc. $\mathrm{A}$. RIT for the fry originating from uninjected females was determined by the formula: RIT = (conc. E-conc. D) $/$ conc. D.

The samples for the measurement of liver EROD activity were taken at the points marked B, C, E and F in Fig. 4, 'Results'.

Thiamine analysis. Immediately after sampling, the fry were put in polypropylene tubes, frozen in liquid nitrogen and kept at $-70^{\circ} \mathrm{C}$ until the chemical analysis. The samples of eggs were handled in a similar way. Total thiamine concentration was analyzed by the high performance liquid chromatography (HPLC) method (Ollilainen et al. 1993), with the enzymatic hydrolysis modified according to Hägg (1995).

Homogenized sample $(5 \mathrm{~g})$ in hydrochloric acid $(0.1 \mathrm{~N} ; 65 \mathrm{ml})$ was autoclaved for $30 \mathrm{~min}$ at $120^{\circ} \mathrm{C}$. After the samples had cooled to room temperature, the $\mathrm{pH}$ was adjusted to between 4.0 and 4.5 with sodium acetate, $5 \mathrm{ml}$ of $5 \%$ clara-diastase (Fluka No: 27540) was added and the samples were incubated in a stirring machine at $37^{\circ} \mathrm{C}$ overnight. Trichloroacetic acid was added to precipitate soluble proteins. The mixture was filtered through Schleicher \& Schuell No: 589 black ribbon filter paper and diluted to $100 \mathrm{ml}$.

Thiamine was oxidized to thiochrome. Five $\mathrm{ml}$ of the sample filtrate was mixed with $3 \mathrm{ml}$ freshly prepared alkaline potassium ferricyanide solution $(0.25 \%$ [w/v] in $15 \% \mathrm{NaOH}$ ). After $1 \mathrm{~min}$ of stirring the mixture was neutralized with $1.5 \mathrm{M}$ ortho-phosphoric acid and passed through a preconditioned solid-phase extraction (SPE) column ( $\mathrm{C}_{18}$, Bond Elut). The column was washed twice with $1.5 \mathrm{ml}$ phosphate buffer $(\mathrm{pH} 7.0)$ and thiochrome was eluted with $1.3 \mathrm{ml}$ of a mixture of methanol and phosphate buffer $(80: 20)$.

The HPLC instrumentation consisted of a Waters 501 HPLC pump and 717 autosampler and a Shimadzu RF535 fluorescence detector. Thiochrome was measured at an emission wavelength of $435 \mathrm{~nm}$ and an excitation wavelength of $366 \mathrm{~nm}$. A Waters Novapak C18 reverse-phase column ( $5 \mu \mathrm{m}, 150 \times 3.9 \mathrm{~mm}$ i.d.) was used. The injection volume was $10 \mu \mathrm{l}$ and the mobile phase was a mixture of methanol and phosphate buffer $(30: 70)$ at a flow rate of $1 \mathrm{ml} \mathrm{min}{ }^{-1}$. A thiamine hydrochloride standard (Merck No: 8181 ) was treated in the same manner as the samples. 
Astaxanthine analysis. The muscle, egg and fry samples were put in polypropylene tubes immediately after sampling, frozen in liquid nitrogen and kept at $-70^{\circ} \mathrm{C}$ to await chemical analysis.

Astaxanthine was analyzed by a modification of the HPLC method presented by Christophersen et al. (1989).

Five grams of homogenized white muscle tissue or $1 \mathrm{~g}$ of eggs or yolk sac fry was mixed with a 3 -fold amount of anhydrous sodium sulphate and the mixture was allowed to stand for $1 \mathrm{~h}$. The colour of the sample was extracted with $50 \mathrm{ml}$ (muscle) or $20 \mathrm{ml}$ acetone (eggs and yolk-sac fry) for 3 periods of $30 \mathrm{~min}$ on a horizontal shaker, and the extracts were passed through filter paper, combined and rotary evaporated below $+50^{\circ} \mathrm{C}$. The residue in the case of eggs and yolk-sac fry was dissolved in $2 \mathrm{ml}$ of $99 \%$ ethanol. For the muscle samples, the residue was dissolved in $10 \mathrm{ml}$ hexane and uncoloured lipids removed by a pipette, after which the evaporation was repeated and the pigments dissolved in $2 \mathrm{ml} 99 \%$ ethanol.

The standard stock solution of $1 \mathrm{mg} \mathrm{ml}^{-1}$ astaxanthine (Roche) in chloroform was stored in the dark under nitrogen at $-20^{\circ} \mathrm{C}$, and working solutions of $1 \mu \mathrm{g} \mathrm{ml}^{-1}$ were made daily and their concentrations checked spectrophotometrically. The standard concentration was calculated from the peak absorbances at $485 \mathrm{~nm}$ in chloroform using extinction coefficient 1900 . The serial dilutions for the standard curve were made from the working solution. The standards and samples were passed through a $0.45 \mu \mathrm{m}$ filter (Millipore) prior to HPLC.

HPLC was performed on a HP Hypersil BDS $(250 \times$ $4 \mathrm{~mm}$ i.d.) column with a mobile phase mixture of $80 \%$ $\mathrm{MeOH} / \mathrm{H}_{2} \mathrm{O}(9: 1)$ and $20 \%$ ethyl acetate. The injection volume was $10 \mu \mathrm{l}$ and the mobile phase flow rate $1 \mathrm{ml}$ $\mathrm{min}^{-1}$. Visible spectrophotometric detection was set to $472 \mathrm{~nm}$. The HPLC instrument consisted of Waters model 510 HPLC pump, 717 Plus autosampler, a 486 Tunable absorbance detector and a system interface module.

EROD analysis. After 432 to 454 day-degrees post fertilization the liver of 20 yolk-sac fry ( 2 pools with 10 livers in each) from each of the groups of Expt 3 were sampled into small polypropylene tubes in melting ice. The livers were frozen in liquid nitrogen within 10 min of decapitation of the fry and kept at $-70^{\circ} \mathrm{C}$ until the analysis of EROD activity. The liver samples were homogenized by sonication (Branson Sonifier 250) for $10 \mathrm{~s}$ in $0.15 \mathrm{ml}$ of $\pm 0^{\circ} \mathrm{C} 0.25 \mathrm{M}$ saccharose, and centrifuged at $9000 \times g$ to give a post-mitocondrial supernatant (S-9 fraction). All the samples were prepared at $4^{\circ} \mathrm{C}$. EROD activity was measured from the S-9 fraction with the fluorescence method described by Hodson et al. (1991), with the exception that we used an incubation temperature of $20^{\circ} \mathrm{C}$. All the standards and sam- ples were assayed in duplicate. The correlation coefficient of the standard curve must be over 0.98 . As a control sample we used $\beta$-naphthoflavone induced fish liver microsomes. The purity of the ethoxyresorufin and resorufin was adjusted spectrophotometrically once a week, ethoxyresorufin according to Klotz et al. (1984) and resorufin according to van den Heuwel \& Munkittrick (1995). The detection limit of the enzyme activity was 5 pmol $\mathrm{mg}^{-1}$ protein $\mathrm{min}^{-1}$.

Microbiological and pathological studies. In order to exclude etiologies other than M74 as a cause of death, a normal autopsy involving examination for the presence of ectoparasites on the gills and skin, and bacteriological and virological examinations were carried out according to Midtlyng et al. (1992). Moribund fry (only in 1994) were fixed in neutral buffered $10 \%$ formalin, embedded in paraffin and stained with haematoxylin and eosin. For the bacteriological tests swabs from the kidney area of the fry were streaked on bovine blood agar (tryptic soy agar, CASO, Merck, Germany, containing $5 \%$ blood) and modified ShottsWaltman agar containing $0.03 \%$ bromthymol blue instead of the $0.0003 \%$ suggested in the original article by Waltman \& Shotts (1984). The agar plates were incubated aerobically at $22^{\circ} \mathrm{C}$ for $7 \mathrm{~d}$. The virological methodology described by Midtlyng et al. (1992) was employed for the incubation of samples inoculated into BF-2, RTG-2, FHM or CHSE cells (2 to 3 cell lines per virological examination) at $15^{\circ} \mathrm{C}$. In addition to the fry, the post-stripping brood fish (both males and females) were also tested virologically and for the presence of Renibacterium salmoninarum by the following methodology. A piece of kidney was homogenized 1:10 (w/v) in peptone-saline. The homogenate was centrifuged at $2200 \times g$ at $4^{\circ} \mathrm{C}$ and the supernatant was discarded. The pellet was resuspended 1:1 in peptone-saline and inoculated with a loop on KDM2 and SKDM (Evelyn 1977. Austin et al. 1983), using a growth supplement according to Evelyn et al. (1990). The plates were covered with plastic foil, incubated at $15^{\circ} \mathrm{C}$ and examined for typical colonies once a week for $12 \mathrm{wk}$.

Statistics. Statistical analysis were carried out with Spss/pct analytical software package (Norušis 1986). The likelihood ratio $G$-test and Spearman rank correlation were calculated according to Sokal \& Rohlf (1995), however.

Thiamine bathing of the yolk-sac fry (Expt 1): The effect of the thiaminehydrochloride baths on mortality was analysed by the Friedman test ( $\chi^{2}$ statistic) 3 times after the baths: 2 d (i.e. 30 day-degrees) after bathing, when cumulative mortality in the control group was found to have exceeded $70 \%$ (i.e. 72 to 326 daydegrees after bathing) and on the last day of the experiment (30 June 1995, 360 day-degrees after bathing). The sign test after the Bonferroni method (Sokal \& 
Rohlf 1995) was used to determine which treatment results differed significantly from the others.

Injection trials with adult females (Expt 2): The Gtest was used to study the effect of the injections on the mortality data for the injected female brood fish. The significance of the differences in the thiamine, astaxanthine and mortality data between the treatment groups was studied using the Kruskal-Wallis test. The Mann-Whitney $U$-test after the Bonferroni method (Sokal \& Rohlf 1995) was performed to decide which populations were not identical to the others.

Expt 3: Pairwise comparison of EROD activities in the offspring of the injected and non-injected females was performed using the Mann-Whitney $U$-test. The unbathed and bathed groups were compared using the Wilcoxon matched-pairs signed-ranks test or - when appropriate - the sign test. Because of the extreme asymmetry of 3 of the distributions of the values for liver EROD activity in the yolk-sac fry (Fig. 3, 'Results'), the values were transformed by taking $\log _{10}$ of the EROD activities before the Wilcoxon test. Whole body total thiamine values were compared between the treatment groups using the tests presented in Table 3 . The association between the relative increase in RIT and liver EROD activity was analysed using Spearman rank correlation.

\section{RESULTS}

The detection limit for thiamine in this system was estimated to be $30 \mathrm{pg}$. Reproducibility was tested using egg and liver samples. The intratest reproducibility (variation within a day) was calculated as a CV\% (coefficient of variation): 4.0 for egg samples and 4.6 for liver samples. Recovery percentages were between 61 and $87 \%$ for liver samples and between 72 and $100 \%$ for egg and fry samples.

The fish in the control groups showed signs which have been seen in connection with the M74 syndrome in feral Baltic salmon yolk-sac fry in Sweden (Norrgren et al. 1993, Börjeson et al. 1995). The fish became light in colour, and lost their flight reaction to a spotlight, after which they fell to the bottom of the tray and became unable to swim normally. At a glance only 0 to 5 of the total of about 4000 to 5000 fry tray $^{-1}$ were swimming in an atactic manner. Neither exophthalmus, bleedings nor oedema or white precipitates in the yolk-sac were consistently found in all the fry lying on the bottom of the trays - although each was present in some of them. The yolk-sac of the fry in the control groups had been used less than that of the seemengly healthy fry in the treated groups. The pathological, parasitological, bacteriological and virological examinations of the moribund fry did not reveal any infectious causal agent. The virological and bacteriological examinations of the brood fish were also negative.

\section{Thiamine bathing of the yolk-sac fry (Expt 1)}

Mortality in the control groups occurred rapidly, the whole group dying within a few days of the onset of signs of M74 (Fig. 1). A cumulative mortality of $70 \%$ was reached 85 to 326 day-degrees after the bathing. Mortality also occurred in the treated groups, especially in the $500 \mathrm{mg} \mathrm{l}^{-1}$ series (Fig. 2a), and the eventual mean cumulative mortality values were $99 \%$ in the control series, $80 \%$ in the $500 \mathrm{mg} \mathrm{l}^{-1}$ series, $28 \%$ in the $2500 \mathrm{mg} \mathrm{l}^{-1}$ series and $14 \%$ in the $12500 \mathrm{mg} \mathrm{l}^{-1}$ series. Although the lower treatment concentrations did not give as good a protection as $12500 \mathrm{mg} \mathrm{l}^{-1}$, it is evident from Fig. 2a that they did delay the onset of the mortality.

It can be concluded from the Friedman $\chi^{2}$ test statistic for the cumulative mortality data that the 4 treatments were followed by different levels of mortality (significance $\mathrm{p}=\mathrm{ca} 0.73$ and $\chi^{2}=1.20,2 \mathrm{~d}$ after bathing, but $p<0.001$ and $\chi^{2}=$ ca 17.23 at the 2 later
Fig. 1. Cumulative mortality in the control groups of Expt 1 (BS1890 etc. are the labels assigned to the females from which the fry originated)
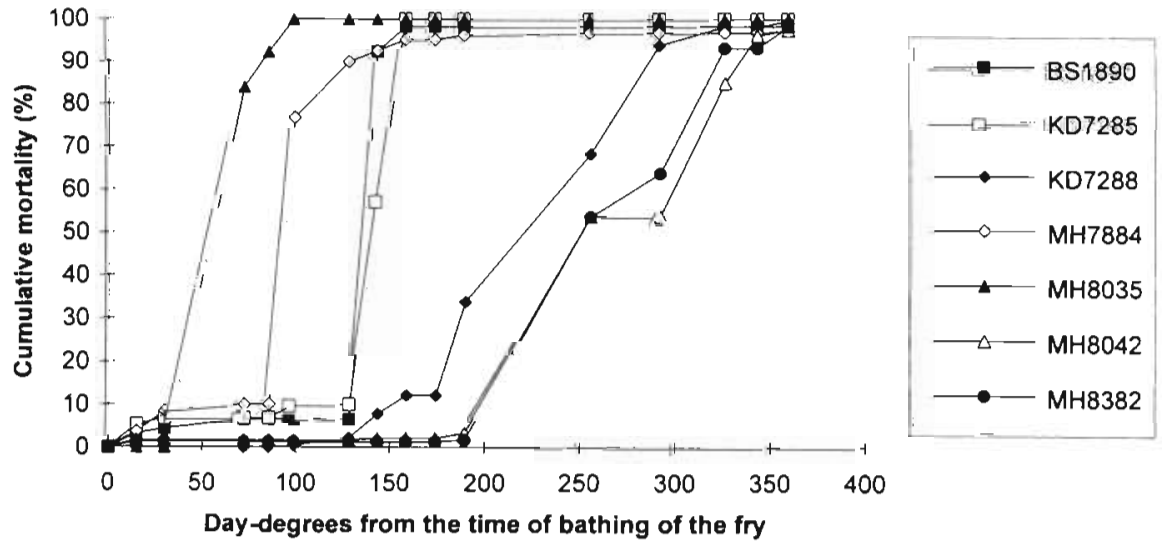
points in time). Treatment with thiamine hydrochloride resulted in a lower mortality among the offspring of all 7 females when comparisons were made after the control groups had reached a cumulative mortality of $70 \%$ (2-tailed significance value $\mathrm{p}=$ ca 0.09 in the sign test after Bonferroni adjustment). At the end of the experiment the $500 \mathrm{mg} \mathrm{l}^{-1}$ group no longer differed from the control group (Fig. 2a, p = ca 0.45 in the sign test), but the $2500 \mathrm{mg} \mathrm{l}^{-1}$ and $12500 \mathrm{mg} \mathrm{I}^{-1}$ groups still had a lower cumulative mortality than the control and 500 mg $\mathrm{l}^{-1}$ groups (Fig. 2a, p = ca 0.09 in the sign test after Bonferroni adjustment). No difference could be found between the $2500 \mathrm{mg} \mathrm{l}^{-1}$ and $12500 \mathrm{mg} \mathrm{l}^{-1}$ thiamine hydrochloride groups (Fig. $2 \mathrm{a}, \mathrm{p}=1.00$ in the sign test).

The results of the thiamine analyses of the fry are presented in Table 1 . The total thiamine concentration in fry showing $\mathrm{M} 74$ signs was $0.19 \pm 0.01 \mathrm{mg}$ $\mathrm{kg}^{-1}$ (mean \pm standard error of mean), with a range of 0.16 to $0.22 \mathrm{mg} \mathrm{kg}^{-1}$. That in the untreated fry, measured 1 to $2 \mathrm{~d}$ (13 to 28 day-degrees) before the bathing, was $0.14 \pm 0.01 \mathrm{mg} \mathrm{kg}^{-1}$, with a range of 0.10 to $0.17 \mathrm{mg} \mathrm{kg}^{-1}$.

\section{Injection trials with adult females (Expt 2)}

The pre-stripping mortality among the i.p.-injected females was $4 / 39$, compared with $1 / 9$ in the uninjected control group. The $G$-test result of $G^{2}=$ ca 0.006 (p > 0.90 , df $=1$ ) strongly suggests that mortality was not related to the injection. The G-test was also used to compare the frequencies of mortality in the 4 treatment groups, and again the result $\left(G^{2}=\mathrm{ca} 6.242, \mathrm{p}>0.10\right.$, df $=3$ ) did not suggest any relation between the treatment and mortality among the female fish.

The total thiamine levels in the newly stripped eggs and yolk-sac fry are presented in Table 2. The mean thiamine concentration in the eggs of the females injected only with thiamine was $4.88 \mathrm{mg} \mathrm{kg}^{-1}$ as compared with $0.28 \mathrm{mg} \mathrm{kg}^{-1}$ in eggs from the untreated females, a significant difference. The corresponding values for the yolk-sac fry were 3.90 and $0.24 \mathrm{mg} \mathrm{kg}^{-1}$, again a significant difference. Injection of the astaxanthine suspension had no significant influence on the thiamine values of the eggs or fry. The mean percentage decrease in thiamine concentration from newly stripped eggs to yolk-sac fry was nevertheless greatest in the group which received the astaxanthine suspension (Table 2), and the percentage decrease in thiamine concentration from newly stripped eggs to yolk-sac fry was greater in the group which received thiamine and astaxanthine than in the control or thiamine group. This difference was not statistically significant, however (Table 2). The p-values after Bonferroni adjustment of the Mann-Whitney $U$-test were 0.16 and 0.29 , respectively.

The astaxanthine concentrations in the groups which received the astaxanthine suspension were 2.70 and $2.33 \mathrm{mg} \mathrm{kg}^{-1}$ on average as compared with 0.67 and $0.86 \mathrm{mg}$ $\mathrm{kg}^{-1}$ in the groups which did not

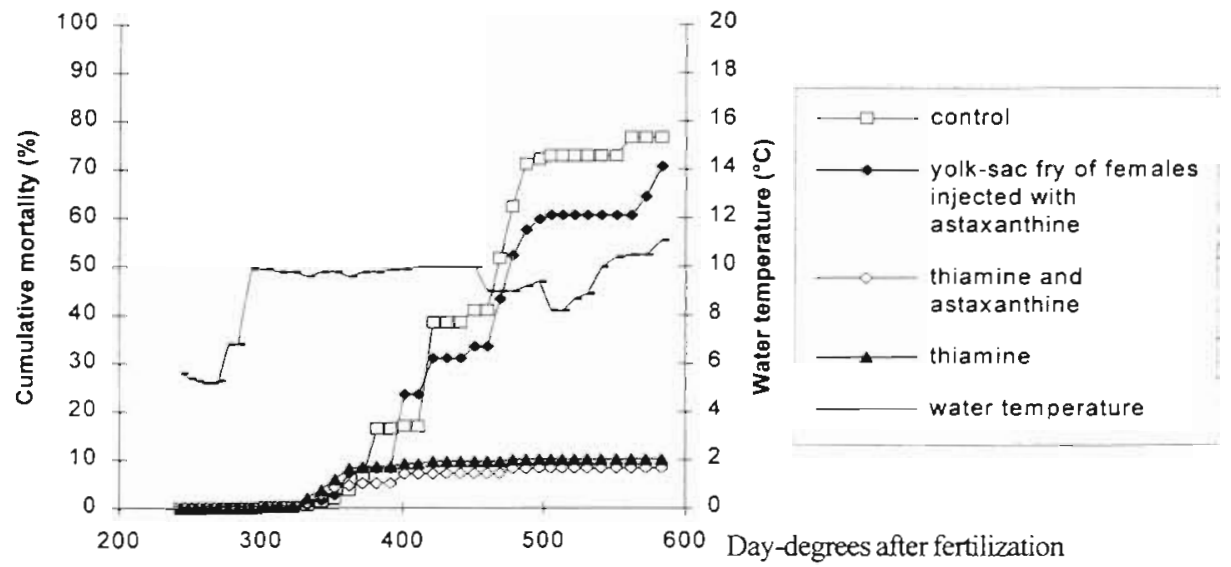

Fig. 2 (a) Mean cumulative mortality of yolk-sac fry after the various thiamine hydrochloride baths in Expt 1 and water tem-

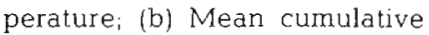
mortality of the yolk-sac fry of the injected female brood fish in Expt 2 and water temperature 
Table 1. Whole-body total thiamine concentrations ( $\mathrm{mg} \mathrm{kg}^{-1}$ ) in the fry of Expt 1

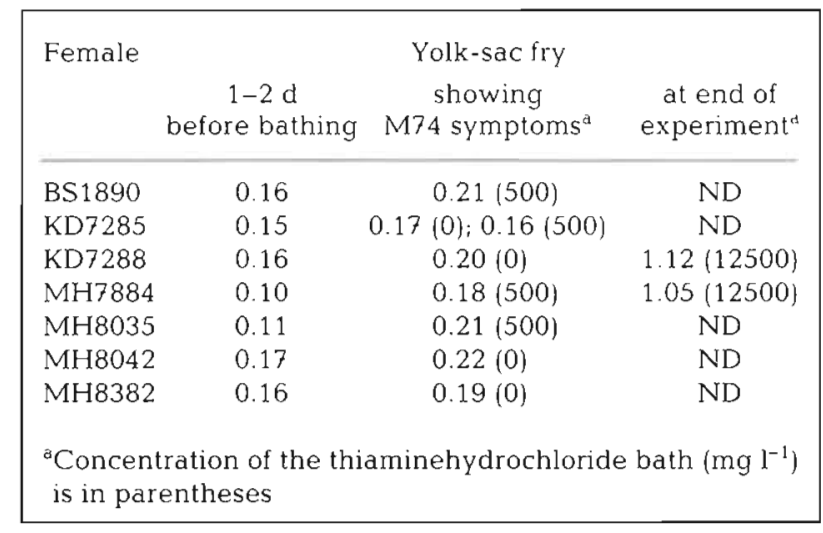

receive an astaxanthine injection (Table 2). According to the Bonferroni-adjusted Mann-Whitney U-test, we can be $99 \%$ sure that the values for the former groups will be greater than those for the last-mentioned ones (Table 2).

The curves for mean cumulative mortality during Expt 2 can be seen in Fig. 2b. At the end of the experiment the mean cumulative mortality among the offspring of the females injected with thiamine and thiamine + astaxanthine was only 10 and $8 \%$, respectively, but that in the groups which did not receive thiamine at all was 77 and $67 \%$. It is unlikely that the decrease in mortality would have happened by chance (the p-values after the Bonferroni-adjusted MannWhitney $U$-test $<0.05$, Table 2).

\section{Expt 3}

The whole body total thiamine concentrations for the yolk-sac fry, presented in Table 3 , show that the values of the fry originating from uninjected females had increased ca 2 - to 10-fold after the thiamine hydrochloride bath. The post-bath decrease in total thiamine concentration in the offspring of the thiamine-injected females was smaller than that in their control siblings, although the difference was not statistically significant (Table 3).

The mean EROD activity in the liver of the yolk-sac fry in the 8 control groups was $11.6 \mathrm{pmol} \mathrm{mg}^{-1}$ protein $\mathrm{min}^{-1}$ (range 2.6 to $34.3 \mathrm{pmol} \mathrm{mg}^{-1}$ protein $\mathrm{min}^{-1}$ ). The lowest EROD activities in the controls were detected in the groups with either a low ( 6 to $7 \%, \mathrm{n}=2$ ) or a high $(100 \%, n=4)$ mortality. The mean of the cumulative mortality in the control groups was $63 \%$, range 6 to $100 \%$, the respective values for the offspring of the thiamine-injected females being $19 \%$ and 6 to $24 \%$. These figures differed significantly according to the Mann-Whitney test statistic ( $W=87, \mathrm{n}=8, \mathrm{p} \approx 0.0436$ ).

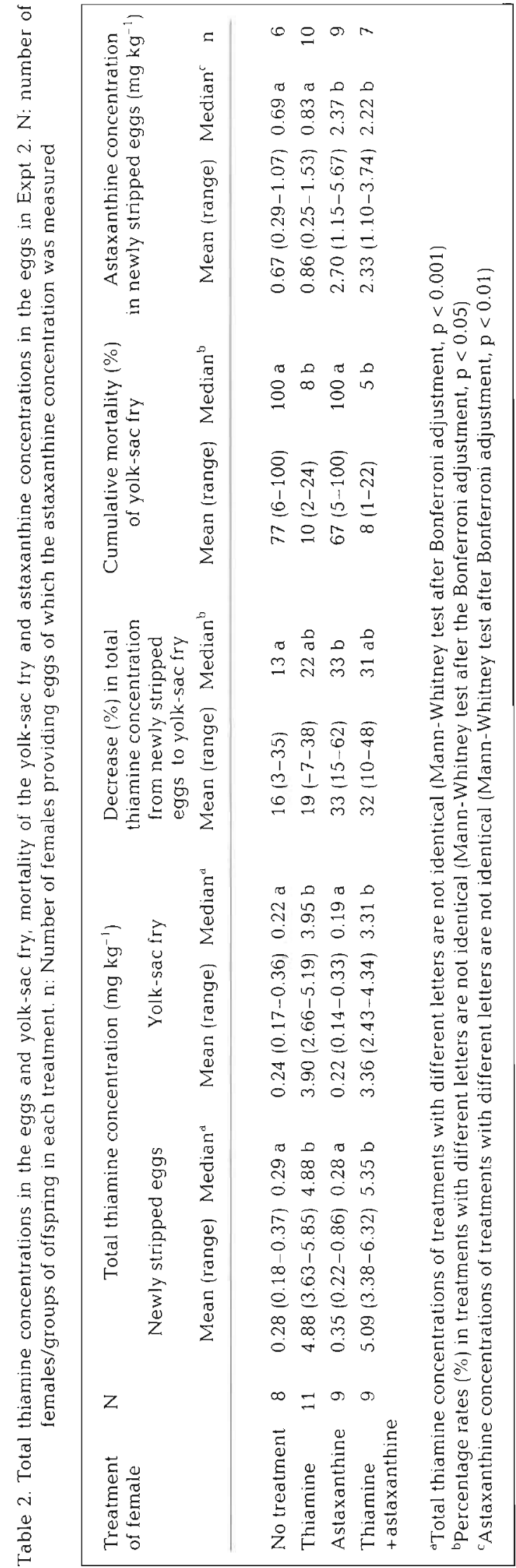


Table 3. Whole body total thiamine concentrations in the yolk-sac fry in Expt 3. A-E as shown in Fig. 4. N; number of groups of yolk-sac fry in each treatment. Different letters $(a, b)$ indicate that the concentrations of the respective treatments in each column are not identical. $\mathrm{ND}=$ test not done. $\mathrm{S}=$ sign test, $\mathrm{p}=0.070 ; \mathrm{W}=$ Wilcoxon matched-pairs signed-ranks test result, $Z=-2.0226$, $\mathrm{p} \approx 0.043 ; \mathrm{M}=$ Mann-Whitney $U$-test result, $W=77, \mathrm{p} \approx 0.345$

\begin{tabular}{|c|c|c|c|c|c|c|c|c|}
\hline \multirow[t]{2}{*}{ Group and sampling time } & & \multirow[t]{2}{*}{$\mathrm{N}$} & \multirow{2}{*}{$\begin{array}{c}\text { Mean } \\
\left(m g \mathrm{~kg}^{-1}\right)\end{array}$} & \multirow{2}{*}{$\begin{array}{c}\text { Range } \\
\left(\mathrm{mg} \mathrm{kg}^{-1}\right)\end{array}$} & \multirow{2}{*}{$\begin{array}{l}\text { Median } \\
\left(\mathrm{mg} \mathrm{kg}^{-1}\right)\end{array}$} & \multicolumn{3}{|c|}{ Statistical test result } \\
\hline & & & & & & $\mathrm{S}$ & $W$ & M \\
\hline \multirow[t]{3}{*}{ Fry of injected females, } & before bathing (A) & 8 & 4.18 & $3.47-5.19$ & 4.08 & a & ND & ND \\
\hline & after bathing (B) & 8 & 3.30 & $2.27-5.95$ & 3.01 & $b$ & ND & $\mathrm{a}$ \\
\hline & control group to B (C) & 8 & 2.91 & $2.20-4.92$ & 2.55 & $b$ & ND & a \\
\hline \multirow[t]{2}{*}{ Fry of noninjected females, } & before bathing (D) & 5 & 0.27 & $0.21-0.36$ & 0.23 & ND & $\mathrm{a}$ & ND \\
\hline & after bathing (E) & 5 & 1.63 & $0.43-2.55$ & 2.20 & ND & $\mathrm{b}$ & ND \\
\hline
\end{tabular}

The effects of thiamine treatment on the EROD activity in the liver of the yolk-sac fry in the different treatment protocols are presented in Fig. 3. EROD activity appeared not to differ significantly between the livers of thiamine-immersed and untreated fry. The Wilcoxon matched-pairs signed-ranks test result for the logarithmic transformation of the values for the offspring of the non-injected females was $-0.4045(n=5, p=0.6858$ ) and that for those of the thiamine-injected females $-1.2603(n=8, p \approx 0.2076$ ). Similarly the EROD activity in the liver of the untreated yolk sac fry of the thi-

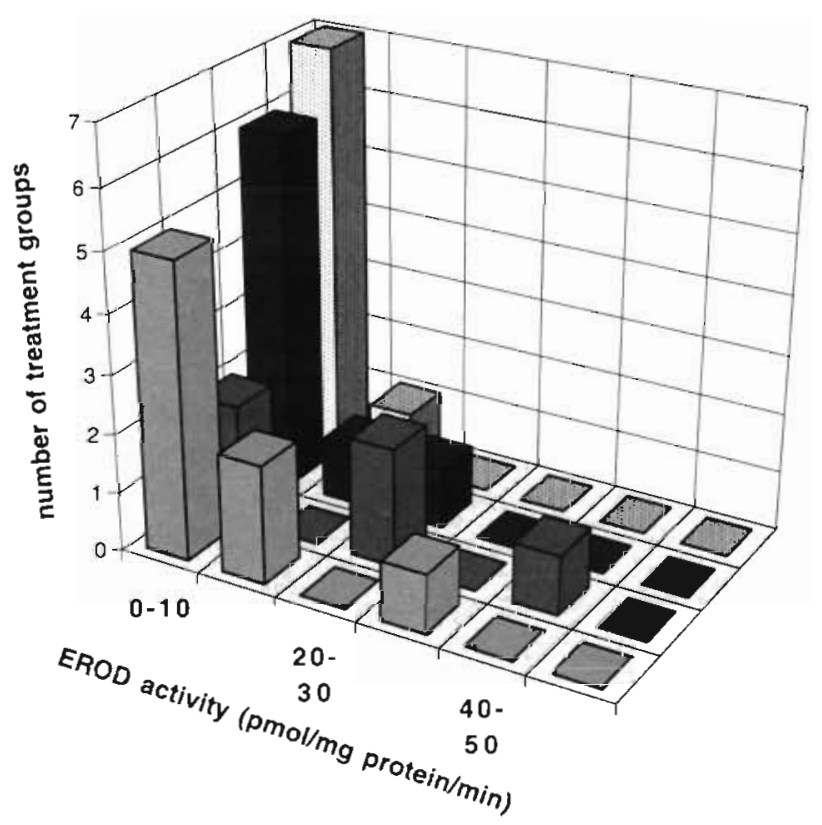

\footnotetext{
Dno injection - no bath, mean EROD activity
$11.6 \mathrm{pmol} / \mathrm{mg}$ prot/min (F in Fig. 4)
no injection - bath, mean EROD activity
$20.4 \mathrm{pmol} / \mathrm{mg}$ prot/min (E in Fig. 4)
injection - no bath, mean EROD activity
$8.5 \mathrm{pmol} / \mathrm{mg}$ prot/min (C in Fig. 4)
injection - bath, mean EROD activity
$5.2 \mathrm{pmol} / \mathrm{mg}$ prot/min (B in Fig. 4 )
}

Fig. 3. EROD activity of the liver of the yolksac fry in the various treatment groups in Expt 3

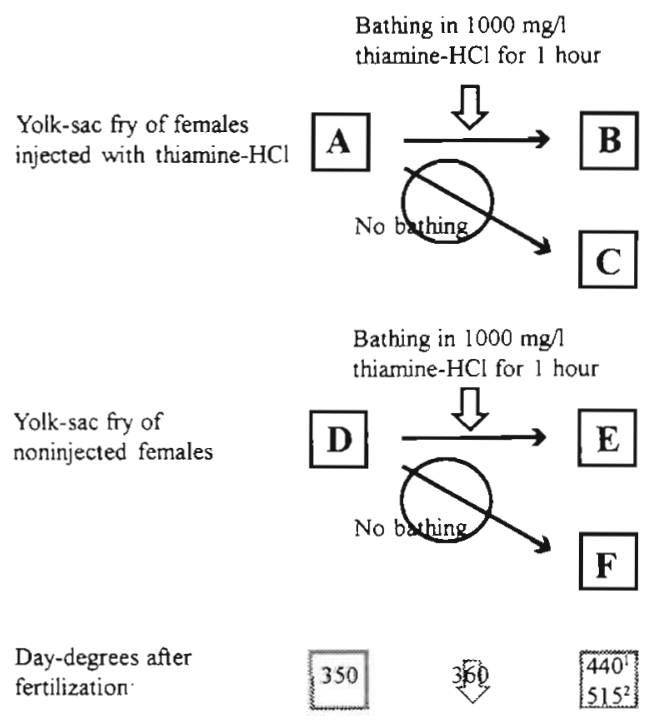

Fig. 4. Symbols for the instances of sampling the yolk-sac fry in Expt $3 .{ }^{1}$ Analysis of ERODi ${ }^{2}$ analysis of thiamine

amine-injected females could not be shown to differ from that in the fry of those left uninjected (MannWhitney test statistic $W=73, \mathrm{n}=8, \mathrm{p} \approx 0.6454)$. The Spearman rank correlation result regarding the association between RIT and liver EROD activity was $I_{s}=$ -0.4524 for the fry of the thiamine injected females $(n=$ 8, $p>0.10$, EROD activities of $B$ [Fig. 4]) and $r_{s}=0.700$ for the fry of the uninjected females $(n=5, p>0.10$, EROD activities of D [Fig. 4]). Thus the null hypothesis of no linear correlation of the ranks of RIT and EROD could not be rejected.

\section{DISCUSSION}

The clinical signs of the dying fry in our control groups resembled those of the M74 syndrome described by Norrgren et al. (1993), Börjeson et al. (1995) and Lundström et al. (1996). The signs tended to 
be mostly lethargy and to a lesser extent atactic swimming, the major sign described by these authors in Sweden. The macroscopic lesions described in fish in Sweden appeared to be less common in our control fry, but were still present. The magnitude, timing and the sudden occurrence of the mortality (Fig. 1), however, and the absence of infectious diseases, strongly suggest that the mortality in our control groups was indeed caused by the M74 syndrome.

\section{Thiamine bathing of the yolk-sac fry (Expt 1)}

The reduction in the yolk-sac fry mortality brought about by the thiamine bathing confirms the result of the preliminary trial by Bylund \& Lerche (1995) on the benefit of thiamine for the treatment of clinical M74 in the Baltic salmon. Our results also show that thiamine hydrochloride baths can be used to prevent the syndrome - as in experiments conducted on yolk-sac fry of the Atlantic salmon suffering from the 'Cayuga Syndrome' in the USA (Fisher et al. 1996b). Our results (preliminarily reported by Koski et al. 1996) show a clear dose-dependent response in the prevention of M74 mortality in the fry by thiamine hydrochloride treatment, suggesting that there could be a causal relationship between the thiamine status of the developing fry and the M74 syndrome. The pathoanatomical changes reported by Lundström et al. (1996) and the thiamine data of Amcoff et al. (1996) also indicate that the deaths of fry suffering from M74 are caused by a thiamine deficiency.

The whole body total thiamine concentration reported for Baltic salmon fry suffering from M74 mortality in Sweden (mean \pm standard deviation, SD, $0.031 \pm$ $0.029 \mathrm{mg} \mathrm{kg}^{-1}$ ) (Amcoff et al. 1996) is clearly lower than ours (mean $0.14 \mathrm{mg} \mathrm{kg}^{-1}$ ), but that found in the Atlantic salmon fry suffering from the early mortality syndrome (EMS) in the Finger Lakes, USA, is close to ours. Fisher et al. (1996b) reported values just above the $0.1 \mathrm{mg}$ $\mathrm{kg}^{-1}$ detection limit of their total thiamine measurement method. The thiamine concentration in viable yolk-sac fry of the Swedish Baltic salmon $(0.428$ $\pm 0.406 \mathrm{mg} \mathrm{kg}^{-1}$. Amcoff et al. 1996) is ca 3 times higher than in our M74 fry.

The lowest concentration of the thiamine hydrochloride used in the baths of this experiment $\left(500 \mathrm{mg} \mathrm{l}^{-1}\right.$ ) was much lower than the $10000 \mathrm{mg} \mathrm{l}^{-1}$ used by Fisher et al. (1994, 1996b) and Bylund \& Lerche (1995). We obtained a short-term effect even with this low concentration (Fig. 1a). As Fisher et al. (1996a) also conclude, the delay in the onset of the yolk-sac mortality obtained with such a low concentration is not good enough for fish farm practice. At the Lautiosaari State Fish Hatchery $1000 \mathrm{mg} \mathrm{l}^{-1}$ thiamine hydrochloride baths for $1 \mathrm{~h}$ have been found effective for the prevention of M74, when given at an age of ca 300 daydegrees after fertilization. Some of the fry need to be re-treated in the late yolk-sac period, however. This method has been found cheaper and easier under the fish farm conditions than the use of $10000 \mathrm{mg} \mathrm{l}^{-1}$. In 1996-97 the bulk of the Baltic salmon fry produced at the Lautiosaari State Fish Hatchery have been treated in this way, resulting in ca $95 \%$ survival of the yolk-sac fry as compared with ca $25 \%$ in the fry from same females when left untreated. As there were no differences in yolk-sac fry mortality during the first $2 \mathrm{~d}$ after the treatments (Fig. 2a), we conclude that the thiamine hydrochloride did not have a negative effect on the fry immediately after the bath.

\section{Injection trials with adult females (Expt 2)}

The mortality rates and whole body thiamine concentrations of the newly stripped eggs and the yolk-sac fry in the treatment groups that received thiamine or thiamine and astaxanthine injection, differ from the values in the other groups (Table 2). The results show clearly that injection of the females with thiamine hydrochloride is of great practical importance in the farming of feral Baltic salmon fry (Table 2, Fig. 2b).

The egg astaxanthine concentrations in the control and thiamine-injected groups (Table 2) were lower than those reported by Pettersson \& Lignell (1996) for the Baltic salmon, where an average astaxanthine concentration of ca $1.8 \mathrm{mg} \mathrm{kg}^{-1}$ was found in the unfertilized eggs of a total of 125 feral females. The concentration in the groups that received the astaxanthine injection was roughly the same as reported by Pettersson \& Lignell (1996) for the Swedish land-locked Lake Vänern salmon-ca $3.4 \mathrm{mg} \mathrm{kg}^{-1}$, but clearly lower than that found by us in newly stripped eggs of the Atlantic salmon in the River Teno, Finland (own unpubl. results, mean concentration ca $8.3 \mathrm{mg} \mathrm{kg}^{-1}$, range 5.1 to $12.0 \mathrm{mg} \mathrm{kg}^{-1}, \mathrm{n}=10$ ). No $\mathrm{M} 74$ syndrome has been observed in Lake Vänern or in the Atlantic salmon of the River Teno. The injection of astaxanthine into the female brood fish did not have any effect on the cumulative mortality of the yolk-sac fry, but we did observe a greater proportional decrease in total thiamine concentration from newly stripped eggs to yolksac fry in the offspring of those females which had received astaxanthine (Table 2). This may indicate an interaction between astaxanthine and thiamine in the developing embryo or fry. In view of the beneficial effect of the thiamine injection alone on mortality of the yolk-sac fry, we do not consider it necessary to include astaxanthine in the injection given to the female brood fish for the prevention of M74. 
Larsson \& Haux (1996) reported that the injection of wiggling prespawning Baltic salmon with $100 \mathrm{mg} \mathrm{kg}^{-1}$ thiamine hydrochloride led to a reduction in wiggling behaviour and mortality. The fact that no wiggling behaviour was observed in our fish may indicate a better general condition or thiamine status in the brood fish than in those used by Larsson \& Haux (1996). The absence of any difference in mortality between the females in the different treatment groups in this investigation may be a reflection of this. Our results do not reveal any harmful effects of thiamine hydrochloride injections for female salmon.

The injection of thiamine into the females at a time when uptake by the eggs is still possible, offers an opportunity for enhancing the reproduction of wild Baltic salmon. According to Jokikokko et al. (1995), there has been a decrease in potential parr densities of feral Baltic salmon to one tenth of early levels in those Finnish rivers where natural reproduction of Baltic salmon still occurs. This collapse took place at the same time as a high increase in yolk-sac mortality among feral Baltic salmon was observed in Finnish fish farming. In our experiment, injection of the females did not affect the mortality of the brood fish at the Lautiosaari fish farm, nor was mortality observed in the wild salmon injected and released into the River Simo in the preliminary trial in 1996 (data not shown). The influence of thiamine injections given to wild females on smolt production in the Finnish Baltic salmon rivers would need further research, however.

\section{Expt 3}

The marked increase in the whole body total thiamine concentration observed in the fry from the noninjected females after the preventive thiamine hydrochloride bath strengthens our conclusion based on Expt 1 that it was the low thiamine status of the fry which was the direct cause of the M74 deaths.

Our results regarding the effect of the different thiamine treatments on EROD activities in the yolk-sac fry (Fig. 3) do not suggest any direct association between EROD values and thiamine treatment. This is particularly interesting because a parallel reduction in the mortality of the yolk-sac fry of the thiamineinjected females was found to that in Expt 2. This result confirms the results of Expts 1 and 2, showing that thiamine treatments reduced mortality in the fry. Our material is relatively small, however, and the variation in the activities is considerable (Fig 3), so that differences in EROD activity between the treatments might be found with a larger material.

Norrgren et al. (1993) reported EROD activities of several hundred pmol $\mathrm{mg}^{-1}$ protein $\mathrm{min}^{-1}$ in the yolk- sac fry of feral Baltic salmon in Sweden. The level of liver EROD activity observed in this work corresponds to values measured in the fry (Norrgren et al. 1993) and juveniles (Grøsvik et al. 1997) of farmed salmon, and the same level of liver EROD activity has been measured in healthy farmed juvenile brown trout (Nakari 1997). Values must be compared with caution between reports, however, because there are many factors like water temperature, sampling method, sample processing and assay method of the enzyme which may affect the results and cause variation in the measures of absolute activities between laboratories (Koivusaari et al. 1981, Munkittrick et al. 1991, Stagg \& McIntosh 1996). For example, EROD activities measured from liver S-9 fractions were reported to be ca one-third to one-quarter of those measured from microsome fractions (Hodson et al. 1991, O'Hare et al. 1995). There are differences between different species, and even within the same species (LindströmSeppä 1990). Also, wild fish respond to stress differently from hatchery-reared fish (Fitzsimons 1995). In our material the groups of both healthy fry (mortality 6 to $7 \%$ ) and M74 fry (mortality 100\%) had low EROD activities in their liver samples, a finding which conflicts with that of Norrgren et al. (1993). The induction or inhibition of EROD activity is known to be quite rapid, only a matter of hours, as has been shown with organic xenobiotics by Pesonen \& Andersson (1991). The personal communication of Norrgren (1995) on the limited duration of EROD induction in the M74 fry emphasizes this further. With regard to the negative result obtained in the attempt to find an association between RIT and liver EROD activity in the yolk-sac fry, it must be said again that our material is too small and its variation is too large to permit any firm conclusions to be drawn.

Acknowledgements. The staff of the Lautiosaari State Fish Hatchery, Keminmaa, Finland, and especially Mr Juhani Rytilahti are warmly thanked for their help in carrying out the experiments. Dr Hannele Tapiovaara and veterinarians Varpu Hirvelä-Koski and Tarja Kujala of the National Veterinary and Food Research Institute, Helsinki and Oulu, Finland, kindly pertormed the virological and bactenological tests and the other staff of these laboratories are also gratefully acknowledged. This work was supported by the Research Council for Environmental Studies (formerly the Research Council for Agriculture and Forestry) of the Academy of Finland.

\section{LITERATURE CITED}

Amcoff P, Norrgren L, Börjeson H, Lindberg J (1996) Lowered concentrations of thiamine (vitamin $B_{1}$ ) in M74-affected feral Baltic salmon (Salmo salar). In: Bengtson BE, Hill C, Nellbring S (eds) Report from Second Workshop on Reproduction Disturbances in Fish, 20-23 November 1995. Swedish Environmental Protection Agency Report 4534, Stockholm, p 38-39 
Austin B, Embley TM, Goodfellow M (1983) Selective isolation of Renibacterium salmoninarum. FEMS (Fed Eur Microbiol Soc) Microbiol Lett 17:111-114

Bylund $G$, Lerche $O$ (1995) Thiamine therapy of $M 74$ affected fry of Atlantic salmon Salmo salar. Bull Eur Assoc Fish Pathol 15:93-97

Börjeson H, Norrgren L, Andersson T, Bergquist PA (1995) The Baltic salmon - situation in the past and today. In: Norrgren L (ed) Report from Uppsala Workshop on Reproduction Disturbances in Fish, 20-23 November 1993. Swedish Environmental Protection Agency Report 4346, Stockholm, p 14-25

Christophersen AG, Knuthsen P, Skibsted LH (1989) Determination of carotenoids in salmonids. $Z$ Lebensm 188: $413-418$

Evelyn TPT (1977) An improved growth medium for the kidney disease bacterium and some notes on using the medium. Bull Off Int Epizoot 87:511-513

Evelyn TPT, Prosperi-Porta L, Ketcheson JE (1990) Two new techniques for obtaining consistent results when growing Renibacterium salmoninarum on KDM2 culture medium. Dis Aquat Org 9:209-212

Fisher JP, Spitsbergen JM, Combs GF, Babenzein M, Chiotti $T$ (1994) Wild-caught Atlantic salmon from New York's Finger Lakes: epizootiology of the 'Cayuga Syndrome' In: Sippel A (ed) Proceedings of EMS Workshop (Ann Arbor, Michigan, USA, July 12-14, 1994), Ann Arbor, p 15

Fisher JP, Spitsbergen JM, Getchell R, Symula J, Skea J, Babenzein $M$. Chiotti $T$ (1995) Reproductive failure of landlocked Atlantic salmon from New York's Finger Lakes: investigations into the etiology and epidemiology of the 'Cayuga Syndrome'. J Aquat Anim Health 7:81-94

Fisher JP, Brown S, Browser PR, Wooster GA, Chiotti T (1996a) Continued investigations into the role of thiamine and thiaminase-rich forage in the Cayuga syndrome of New York's landlocked Atlantic salmon. In: Bengtson BE, Hill C, Nellbring S (eds) Report from Second Workshop on Reproduction Disturbances in Fish, 20-23 November 1995. Swedish Environmental Protection Agency Report 4534, Stockholm, p 79-81

Fisher JP, Fitzsimons JD, Combs Jr GF, Spitsbergen JM (1996b) Naturally occurring thiamine deficiency causing reproductive failure in Finger Lakes Atlantic salmon and Great Lakes lake trout. Trans Am Fish Soc 125:167-178

Fitzsimons JD (1995) A critical review of the effects of contaminants on early life stage (ELS) mortality of lake trout in the Great Lakes. J Gt Lakes Res 21:267-276

Grøsvik BE, Larsen HE, Goksøyr A (1997) Effects of piperonyl butoxide and $\beta$-naphtoflavone on cytochrome P4501A expression and activity in Atlantic salmon (Salmo salar L.). Environ Toxicol Chem 16:415-423

Hägg $M$ (1995) Determination and contents of thiamine and riboflavin in finnish animal products and in Finnish and imported rye and cereal products. Academic dissertation. Department of Biochemistry and Pharmacy, Åbo Akademi University, Åbo, Finland and Laboratory of Food Chemistry, Agricultural Research Centre of Finland, Jokioinen, Finland

Hodson PV, Kloepper-Sams PJ, Munkittrick KR, Lockhart WL, Metner DA, Luxon PL, Smith IR, Gagnon MM, Servos M, Payne JF (1991) Protocols for measuring mixed fuction oxygenases of fish liver. Can Tech Rep Fish Aquat Sci 1829

Jokikokko E, Romakkaniemi A, Jutila E (1995) M74-phenomenon and the natural salmon production in the rivers Simojoki and Tornionjoki, northern Finland. ICES CM 1995/M:29 (poster, abstract)
Klotz AV, Stegeman JJ, Walsh C (1984) An alternative 7 ethoxyresorufin $O$-deethylase activity assay: a continuous visible spectrophotometric method for measurement of cytochrome P-450 monooxygenase activity. Anal Biochem 140:138-145

Koivusaari U, Harri M, Hänninen O (1981) Seasonal variation of hepatic biotransformation in female and male rainbow trout (Salmo gairdneri). Comp Biochem Physiol 70C: 149-157

Koski P, Pakarinen M, Soivio A (1996) A dose-response study of thiamine hydrochloride bathing for the prevention of yolk-sac mortality in Baltic salmon fry (M74 syndrome). In: Bengtson BE, Hill C, Nellbring S (eds) Report from Second Workshop on Reproduction Disturbances in Fish, 20-23 November 1995. Swedish Environmental Protection Agency Report 4534, Stockholm, p 46

Larsson J, Haux C (1996) Possible roles of thiamine, thiaminases and other thiamine inactivating factors in the EMS/M74 syndromes. In: Bengtson BE, Hill C, Nellbring S (eds) Report from Second Workshop on Reproduction Disturbances in Fish, 20-23 November 1995. Swedish Environmental Protection Agency Report 4534, Stockholm, p $40-41$

Lignell $\AA$ (1995) Astaxanthin in yolk-sac fry from feral Baltic salmon. In: Norrgren L (ed) Report from Uppsala Workshop on Reproduction Disturbances in Fish 20-23 November 1993. Swedish Environmental Protection Agency Report 4346, Stockholm, p 94-96

Lindström-Seppä P (1990) Biotransformation in fish: monitoring inland water pollution caused by pulp and paper mill effluents. PhD thesis. Publications of the University of Kuopio, Original reports $8 / 1990,26 \mathrm{pp}$

Lundström J, Norrgren L, Börjeson H (1996) Clinical and morphological studies of Baltic salmon yolk-sac fry suffering from the M74 syndrome. In: Bengtson BE. Hill C, Nellbring $S$ (eds) Report from Second Workshop on Reproduction Disturbances in Fish, 20-23 November 1995. Swedish Environmental Protection Agency Report 4534, Stockholm, p 26-27

Midtlyng PJ, Helgason S, Jansson E, Mortensen A, RimailaPärnänen E (1992) Nordic manual for the surveillance and diagnosis of diseases in farmed salmonids. Nordiske Seminar- og Arbejdsrapporter 1992:545, Copenhagen, 65 pp

Munkittrick KR, van den Heuvel MR, Stegeman JJ, Metner DA, Lockhart WL, Payne JF, Hodson PV, Kennedy $S$, Bureau J, Smith IR, Adams M, Miller JA, Martel P (1991) An interlaboratory comparison of the ethoxyresorufin- $O$ deethylase assay for MFO activity. 18th Aquatic Toxicology Workshop, Ottawa, October 1991

Nakari T (1997) Seasonal changes in fish biomarkers. Ann Zool Fenn 34:115-126

Norrgren L, Andersson T, Bergqvist PA, Björklund I (1993) Chemical, physiological and morphological studies of feral Baltic salmon (Salmo salar) suffering from abnormal fry mortality. Environ Toxicol Chem 12:2065-2075

Norušis MJ (1986) SPSS/PC+ for the IBM PC/XT/AT, version V3.0 (manual). SPSS Inc., Chigaco

O'Hare DB, Robotham BWJ, Gill R (1995). Erod measurement using post mitochondrial supernatant (pms) in roach (Rutilus rutilus L.), a possible biomonitor for $\mathrm{PAH}$ contamination in the freshwater environment. Chemosphere 30 : $257-264$

Ollilainen V, Vaahteristo L, Uusi-Rauva A, Varo P, Koivistoinen P, Huttunen J (1993) The HPLC determination of total thiamin (vitamin $B_{1}$ ) in foods. J Food Compos Anal 6 : $152-165$

Pesonen M, Andersson T (1991) Characterization and induc- 
tion of xenobiotic metabolizing enzyme activities in a primary culture of rainbow trout hepatocytes. Xenobiotica 21:461-471

Pettersson A, Lignell $\AA$ (1996) Decreased astaxanthin levels in the Baltic salmon and the M74 syndrome. In: Bengtson BE, Hill C, Nellbring S (eds) Report from Second Workshop on Reproduction Disturbances in Fish, 20-23 November 1995. Swedish Environmental Protection Agency Report 4534, Stockholm, p 28-29

Sokal RR, Rohlf FJ (1995) Biometry: the principles and practice of statistics in biological research, 3rd edn. WH Freeman and Company, New York

Stagg RM, McIntosh A (1996) Hydracarbon concentrations in the North Sea and effects on fish larvae. Sci Total Environ

Editorial responsibility: Otto Kinne (Managing Editor), Oldendorf/Luhe, Germany
186:189-201

van den Heuvel MR, Munkittrick KR, Stegeman JJ, Dixon DG (1995) Second-round interlaboratory comparison of hepatic ethoxyresorufin-O-deethylase activity in white sucker (Catostomus commersoni) exposed to bleached-kraft pulp mill effluent. Environ Toxicol Chem 14:1513-1520

Vuorinen PJ, Paasivirta J, Keinänen M, Koistinen J, Rantio T, Hyötyläinen T, Welling L (1997) The M74 syndrome of Baltic saimon (Salmo salar) and organochlorine concentrations in the muscle of female salmon. Chemosphere 34: $1151-1166$

Waltman DW, Shotts EB (1984) A medium for the isolation and differentiation of Yersinia ruckeri. Can J Fish Aquat Sci 41:804-806

Submitted: October 11, 1997; Accepted: June 3, 1999 Proofs received from author(s): August 23, 1999 